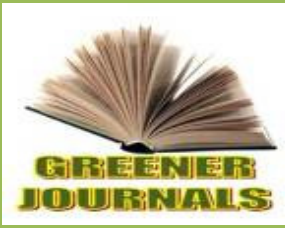

\title{
Mycotoxins in Foods and Indoor Air: Their Attendant Diseases and Modes of Injury on Biological and Human Systems
}

\section{Enyiukwu $\mathrm{DN}^{\star 1}$, Ononuju $\mathrm{CC}^{1}$ and Maranzu $\mathrm{JO}^{2}$}

\author{
1Department of Plant Health Management, Michael Okpara University of Agriculture, Umudike \\ PMB 7267 Umuahia, Abia State, Nigeria. \\ ${ }^{2}$ National Environmental Standards Regulation and Enforcement Agency (NESREA) Owerri Imo \\ State, Nigeria.
}

ARTICLE INFO

Article No.: 010818004

DOI: 10.15580/GJAS.2018.1.010818004

Submitted: 08/01/2018

Accepted: 16/01/2018

Published: 27/01/2018

${ }^{*}$ Corresponding Author

DN Enyiukwu

E-mail: enyidave2003

@gmail.com

Keywords:

Fungi, Mycotoxins, Stored agroproducts, Grain contaminants, Public health, Mode of action (MOA)
Though some secondary metabolites from fungi have found application as antibiotics in modern medicine, majority of these compounds are however known to be hazardous to livestock and human systems. About $\mathbf{4 0 0}$ mycotoxins have been characterized in recent times with each potentially toxic to a biological or human system. Exposure of humans to airborne toxins-carrying spores produced by several species of fungi in water damaged buildings and damp indoor environments have been linked with allergies and sick building syndrome. Contamination of cereals, grains or tubers in the field, transit or store with a broad spectrum of noxious mycotoxins is well reported in literature. Scientific evidences have implicated consumption of such contaminated agricultural products with diseases such as nephropathy, immuno-deficiency, stunted growth, weight loss, onyalai, neural tube defect, CNS depression, kwashiorkor, hepatocellular carcinoma, jaundice, diarrhoea, beriberi and even death. Inhibition of protein synthesis and cell proliferation, inhibition of peptide chain elongation, binding to DNA and uncoupling oxidative phosphorylation, inactivation of ceramide synthase, transferases and other enzymes, and cell wall disruption etc are some of the mechanisms adduced for their toxic activity. With increasing incidence of mycotoxin-related diseases in the developing countries of Africa and other third world economies, concerns about their public health impacts are rife and heightening given that both chronic intermittent and acute exposures are deemed injurious. Therefore an understanding of their modes/mechanisms of injury in biological and human systems will help in tailoring their management in a broad scale. 


\section{INTRODUCTION}

Besides the diseases caused by plant pathogenic fungi in several crops in the field, association of these mycobiota with agro-products during transit or storage could lead to their contamination with dangerous fungiderived toxins (mycotoxins). Mycotoxins are a group of structurally diverse group of low molecular weight compounds produced mainly by filamentous fungi (and sometimes yeasts) which are toxic to biological systems including plants, livestock and humans (Gardiner et al., 2005; Zain, 2011). Fungal infections leading to mycotoxin contamination of feed or foodstuff are predisposed by overcrowding crops in the field, insect infestation of crops in the field or store, and wounds on produce during threshing. Usually contaminations are exacerbated by poor tropical storage conditions characterized by high temperatures and moisture migration (Lacmmelen, 2001).

Worldwide $25 \%$ of agricultural crops covering several cereals, legumes, nuts, and coffee are mycotoxin contaminated (Enyiukwu et al., 2014). In the Czech Republic and Slovenia, Zain (2011) reported that $91 \%$ of raw milk in those countries was mycotoxin contaminated. In a survey in Nigeria up to $98-100 \%$ incidence of the nephrotoxic metabolite ochratoxin A (OTA) from Aspergillus ochraceus and Penicillium verrucosum were detected in cereals (maize, millet, sorghum, sesame and fonio) and red kola nuts obtained from Niger and Oyo states respectively (Adejumo and Adejumo, 2014). A similar survey in the Niger Delta region also recorded $100 \%$ incidence of aflatoxin $B_{1}$ in bread fruit, wheat, millet, and guinea corn. Analysis of semen and blood specimens of infertile men in the area at the University of Benin revealed that $37 \%$ were aflatoxin $B_{1}$ positive. In evaluations in Ogun state southwest Nigeria, the toxin was detected in $90 \%$ of blood and urine specimens, and $58 \%$ in autopsy samples of children with kwashiorkor, suggesting a correlation between the toxin and the debilitating disease (Adejumo and Adejumo, 2014).

Approximately 400 mycotoxins have been reported in literature and all are toxic to humans (Bryden, 2012). Some fungi can produce more than one myccotoxin while some mycotoxins are produced by more than one fungal species (Zain, 2011). Alternaria spp. for instance are known to produce about 70 mycotoxins which include alternatriol $(\mathrm{AOH})$, alternatriol monomethyl ether (AME), alternuen (ALT), tenuzoic acid (TEA), and altertoxins I, II and III (ATX I, II \& III). As high as $116-6432 \mathrm{~g} / \mathrm{kg}(72-89 \%)$ of these toxins have been isolated from a wide range of oils, cereals and cereal products such as bread contaminated with especially $A$. alternata (Nayyar et al., 2014). Others such as aspergic acid, cyclopiozonic acid, kojic acid, naphtoquinones, fumonisins and fusaric acid have been isolated from cereal grains contaminated by Aspergillus niger, Penicillium spp., Fusarium culmorium and Rhizoctonia solani (Haikal, 2008). In addition, literature also shows that $A$. flavus, $A$. niger, $A$. oryzae, and $A$. teneus produce aflatoxin $\mathrm{B}_{1} ; A$. flavus and Penicillium italicum produce fumonisin $B_{1}$ while several Fusarium spp. produce zearalenone (Amadi and Adeninyi, 2009). In Africa however, the mycotoxins considered of most agricultural importance include aflatoxins, ochratoxins, fumonisins, beauvaricin and the trichothecenes such as zearalenone, vomiticin and T-2 toxins (Fig. 1). These toxins impair several biological systems in a variety of ways (Coulombe, 1993).

A plethora of harmful effects on plants, livestock and humans have been attributed to these toxins. In several plant families, toxic fungal metabolites have been reported to decrease growth, yield and yield parameters of crops. Metabolites from $F$. equiseti and Drechslera rostrata retarded root growth; while those from $A$. teneus, $A$. alternata, A. flavus, $F$. solani, $F$. oxysprium reduced the germination of soybean. Toxins screened from $F$. moniliforme retarded the shoot growth of sorghum, Verticillium albo-altro the viability of alfalfa, whereas those from Pythium spp. and Rhizopus sp. reduced the yield of potato (Haikal, 2008). Reduction of leaf length, width and area, leaf chlorophyll content, stomatal density and size on maize by toxic metabolites from $P$. chrysogenum have also been documented (Garuba et al., 2014; Shirurkar and Wahegaonkar, 2014).

In humans, maladies such as allergies, reproductive dysfunction, birth defects, premature puberty in girls, haemorrhage, gene defects, cancers, jaundice, liver damage, kidney damage, immune dysfunction, kwashiokor and even death have been reported due to fungi-derived toxins (Bankole, 2003; Enyiukwu et al., 2014; Shirurkar and Wahegaonkar, 2014). For instance toxic dermatitis and conjunctivitis have been recorded due to improper handling of mycotoxin contaminated hay by farm-hands in Western Nigeria (Amadi and Adeninyi, 2009). According to Bryden (2012) epidemics and outburst of bizarre behavior, low reproductive fertility and high death rates have been linked to food poisoning from mycotoxins in cereal staples from around the world.

Aflatoxins are noted to cause decrease in immunoglobin $A(\lg A)$ in children and to impair human cellular immunity and resistance to diseases. In a study, it was observed that exposure of Dutch peasant processing workers to airborne peanut dusts laden with aflatoxins resulted to increases in the number of those that develop liver and lung cancers compared to their counterparts in a control group (Coulunba, 1993). In subSaharan Africa, and some parts of Asia; aflatoxinsrelated carcinomas resulted in greater than 600,000 deaths on annual basis (Wild and Gong, 2010; Zain, 2011). Scientific evidences suggest a strong correlation between aflatoxin $B_{1}$ on one hand and heptatitis $B$ virus (HBV) and hepatitis $\mathrm{C}(\mathrm{HCV})$ in human hepatocellular carcinoma (HCC) in some parts of China, Malaysia, India and Kenya (Enyiukwu et al., 2014). The fraction of HCC cases attributed to HBV and HCV has been 
estimated to be about $23 \%$ and $20 \%$ in developed countries; and as high as 59\% and 33\% in developing countries respectively (Fig. 2). Also, association of aflatoxins with Reye syndrome -- a disease characterized by encephalopathy, visceral disintegration, and liver and kidney enlargement has been documented (Zain, 2011). Sterigmatocystin a mycotoxin (similar to

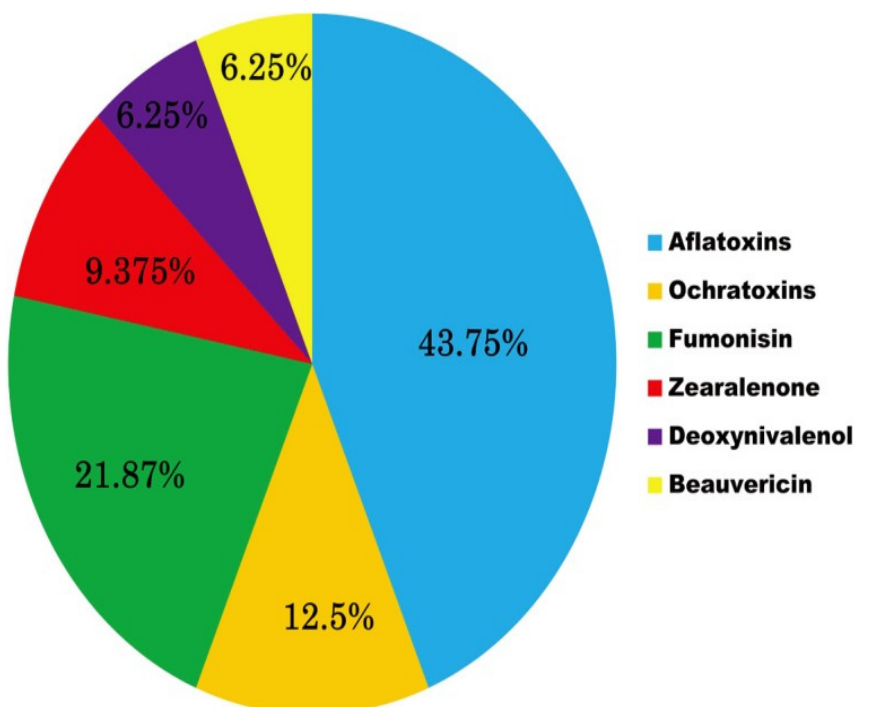

Figure 1: Mycotoxins of most agricultural importance in Africa Sources: Darwis et al. (2014); Shirurkar and Wahegaonkar (2014)

In Denmark, significant contamination of cereals with the ochratoxin A (OTA) have been correlated with high Balkan endemic nephrotrophy (BEN) -- a severe kidney damaging disease in the area (Bankole, 2003; Enyiukwu et al., 2014). In affected human males, OTA is reported to be associated with testicular degeneration, seminiferous tubule atrophy and dissolution of germinative epithelium by interfering with gene transcription through the protagladins synthase route (Anon., 2017). It is also known to cause depletion of dopamine and related compounds in striated tissues (Hope, 2013). Similarly, high prevalence of oesophaeal cancer in the republic of South Africa, China and Northeast Italy has been attributed to large scale consumption of cereal grains such as maize contaminated with fumonisins - a toxin derived from Fusarium spp. (Enyiukwu et al., 2014).

Exposure of humans to water damaged buildings or houses with defective architectural or structural designs; which make for poor indoor air circulation, poor indoor light quality, high degree of dampness and build up of toxin-laden fungal spores of mycotic organisms could lead to sick building syndrome (SBS). SBS has resulted to abandonment, burning and destruction of many houses in the USA and Canada (Peraica et al., 1999; Hope, 2013). Satrotoxins A is one but less toxic to aflatoxin $B_{1}$ ) produced by Bipolaris (Heminsthoporium) spp., Aspergillus nidulans and $A$. vesicolar have been reported to damage the liver, kidney and DNA in human cells by impairing cell cycle, altering DNA, and inhibiting phosphorylation and ATP synthesis (Lillard, 2004).

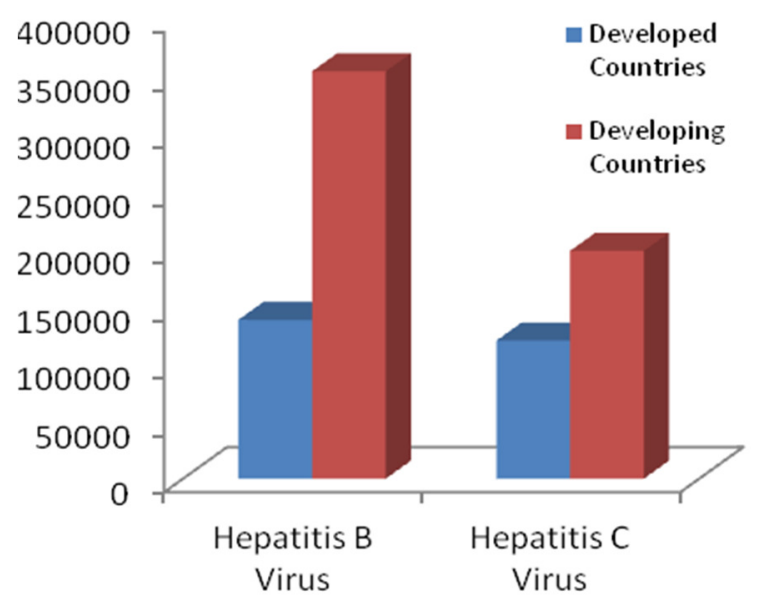

Figure 2: Mycotoxin-related human hepatocellular carcinoma and percent association with HBV and HCV

of the mycotoxins implicated in SBS. It was reported to demonstrate neurological damage in individuals occupying water-damaged buildings at indoor air levels (Hope, 2013). According to this source, this macrocyclic trichothecene in addition to fumonisins, OTA and T-2 have been linked with neuronal degeneration and inflammation in the human brain cortex of fetuses and adults. Verucarins are another group of potent cytotoxic macrocyclic trichothecenes produced by species of Fusarium, Trichoderma, Cephalosporium and other fungi, their mode of injury on biological systems is suspected to border on damaging proliferating cells of the abdomen, bone marrow gastric mucosa and spleen by inhibiting protein and DNA synthesis in the affected organisms (Cudliffe et al., 1974).

Gliotoxins are important aromatic amino acid class of epipolythiodioxopiperazine (ETP) toxins produced by Trichoderma spp., Penicillium spp., A. fumigatus, Gliocladium fimbriatum, and Candida spp. Gliotoxins are thought to be the virulence factor employed by these fungal organisms in macerating and colonizing tissues of immuno-compromised individuals during invasive mycoses (Gardiner et al., 2005). Some of the public health problems due to mycotoxins in Africa are presented in Table 1. 
Table1: Some mycotoxin-related public health problems in some African countries

\begin{tabular}{lll}
\hline Country & Mycotoxin & Disease Caused \\
\hline East Africa, Uganda & Beauvericin & Nodding syndrome (childhood epilepsy) \\
Egypt & Aflatoxins & Primary hepatocellular carcinoma \\
Ghana & Aflatoxins & Anaemia \\
Ghana & Aflatoxins & Immuno-deficiency \\
Gambia & Aflatoxins & Liver cirrhosis \\
Gambia & Aflatoxins & Immunodeficiency \\
Cameroun & Aflatoxins & Primary hepatocellular carcinoma \\
Kenya & Aflatoxins & Aflatoxicosis \\
Nigeria & Aflatoxins & Infertility, Kwashiokor \\
Tunisia & Ochratoxins & Nephropathy \\
Cote d'Ivoire & Ochratoxins & Nephropathy \\
Benin Republic & Aflatoxins & Stunted gowth, under weight \\
Togo & Aflatoxins & Stunted growth, underweight \\
South Africa & Fumonisins & Oesophagal carcinoma \\
\hline
\end{tabular}

Sources: Zain (2013); Duringer et al. (2013); Dobranic et al. (2017)

Worldwide given the role of mycotoxins in human tissues degradation, kwashiorkor, immune dysfunction, cancers and invasive human mycoses, they are considered as major public health problems especially in developing tropical countries; where store hygiene is low, and storage conditions poor thereby, encouraging growth of toxic moulds on feed, foodstuffs and indoors (Eaton and Gallapher, 1994; Shephard, 2008). Also, with the increasing threat of climate change and its accompanying flooding (Salami and Salami, 2011), incidence of sick building syndrome is likely to increase in the near future. It becomes pertinent hence, to document and make handy the modes/mechanisms of action of mycotoxins in affected biological systems and human tissues.

Therefore, this work reviews available literature on some of the diseases caused by fungi-derived toxins from agriculturally and environmentally important mycotoxigenic flora and their modes of injury on biological and human systems.

\section{Diseases caused by mycotoxins in livestock and humans}

Though some studies have shown that gliotoxins has anticancer activity against mammary carcinomas and selectively kills activated hepatic stellate cells in rats without toxicity to the host, majority of the times fungal secondary metabolites are toxic, disrupting cellular responses to fungal infections involving the nicotinamide adenine dinucleotide phosphate oxidase (NADPH oxidase) enzyme complex. They are also reported to prevent viral RNA replication via inhibition of reverse transcriptase (Gardiner et al., 2005). Also, antitumor, antiviral and antibacterial activities due to tenuazonic acid produced by species of Phoma and Alternaria have been documented (Blackmould, 2017). In medicine ergot alkaloids are used in the treatment of Parkinson's disease, migraine, cerebro-vascular insufficiency, and to stimulate the uterus preparatory to parturition (Perraica et al., 1999).

However, majority of times fungal metabolites have been implicated in fatal diseases in livestock and humans. A study in southwest Nigeria found that Wister rats fed samples of paw paw (papaya) fruit contaminated with mycotoxigenic strains of Aspergillus, Fusarium and Rhizopus suffered varying levels of convulsion, paralysis and respiratory attacks (Oyeyipo et al., 2012). Human exposure to water-damaged buildings, endemic with mycotoxin-carrying spores is reported to contribute up to $50 \%$ of human illnesses resulting from indoor air pollution (Hope, 2013).

In humans, fatigue is the primary symptom of the multisystem systemic toxicity that follow exposure to fungal toxins and therefore everyone exposed to mycotoxins will present fatigue and other symptoms such as hair loss, premature hair graying, and coughing up blood or black debris. Others are frequent and burning sensation after urination, nose bleeds, low grade fevers, cognitive dysfunction, joint stiffness, headaches, migraine and brain lesions etc. which may be unwittingly ascribed to other causes (Chronicles, 2014; Anon, 2017).

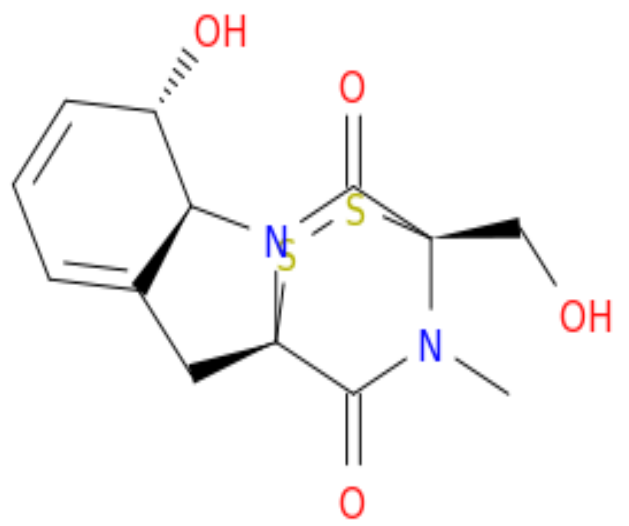

Gliotoxin (Source: ChemEssence.com) 
In China, the toxin 3-nitropropionic acid (3-NPA) produced by Arthrinium spp. have been found associated with mouldy sugarcane poisoning in humans. This disease is characterized by dystonia, convulsion, staring to one side, capopedal spasms and coma. Indoors, moulds spores may not be visible to the human eye; however, they are highly dangerous and life threatening. There is a genetic undertone to indoor air mycotoxicosis. It is reported that at least a quarter of the human populations is unequipped to fight off mycotoxins; these have inherited mutant genes (HLA-DRBQ) which resulted in their immune systems not being able to produce antibodies against mycotoxins (Chronicles, 2014). In Canada and the USA, trichothecene toxins such as satrotoxin $H$, verucanol, verucarins $B$ and $J$, trichoverins $A$ and $B, T-2$ toxin, diacetoxysripenol (DAS) and roridins from airborne spores of Stachybotrys altra,
Trichoderma spp., Fusarium spp., Trichothecum and Myrothecium spp. are reported as major public health problems in water damaged environments being implicated in sick building syndrome (Table 1). These moulds hide behind water damaged walls, around showers and bathtubs, and above damp ceilings (Chronicles, 2014). In affected individuals, the disease presents with cold and flu-like symptoms, sore throat, diarrhoea, headache, fatigue, elevated body temperature, focal alopecia, dermatitis, oral lesions, swelling of the lips and lymph nodes, weak pulse, general malaise and death if allowed to progress (Peraica et al., 1999; Volks and Zitomer, 2002). The disease is especially exacerbated by stressors such as work or psychological problems (Volks and Zitomer, 2002).

Table 1: Mycotoxins involved in Sick building syndrome

\begin{tabular}{llll}
\hline Fungus & Mycotoxins & & \\
\hline Alternaria alternate & $\begin{array}{l}\text { Tenuazonic acid, alternatiol, alternatiol monomethyl ether, } \\
\text { alterotoxins } \\
\text { Aspergillus fumigates }\end{array}$ & $\begin{array}{l}\text { Gliotoxin, } \\
\text { tryptoquivalins }\end{array}$ & verrucologen, fumitremorgceusins,
\end{tabular}

A. ustus

A. versicolor

Chaetomium globosum

Memnoniella echinata

Penicillium aurantiogriseum

P. brevicompactum

P. chrysogenum

Stachybotrys chartarum

Trichoderma harzianum

Wallemia sebi
Austamide, austdiol, austins, austocystins, kotanin

Sterigmatocystin, 5-methoxysterimatocystin, versicolorins

Chaetoglobosins, chaetomin

Trichodermol, trichodermin, emnobotrins $A$ and $B$, memnoconol, memnoconone

Auranthine, penicillic acid, verrucosidin, nephrotoxic glycopeptides

Mycophenolic acid

Roquefortine C, meleagrin, chrysogin

Satratoxins, verrucarins, roridins, atranones, dolabellanes, stachybotrylactones and lactams, stachybotrydialis

Alamethicins, emodin, suzukacillin, trichodermin

walleminols $A$ and $B$

Source: Dobranic et al. (2017) *Toxins in bold are very harzardous 
Human exposure to mycotoxins can occur by several ways, including ingestion, skin contact, and inhalation (Zain, 2011). In certain environments or occasions, public health experts or environmental health professionals may suspect mould exposure, toxicity or sensitivity in an individual, if amongst other factors:

Musty odours bother the patient?

The patient have worked or lived in a building where the air vents were discoloured?

He noticed water damage or discolorations on ceilings or elsewhere in his house or office?

His home had been flooded

He had leaks in the roof of his house?

He experiences shortness of breath?

He experiences recurring sinus infections?

He experience recurring bronchial infections and coughing?

He has flu-like symptoms?

He notices an increase of symptoms on rainy days?

He has frequent headaches?

He is fatigued and has a skin rash? (https://www.ehcd.com/mold-and-mycotoxins)

Trichothecenes are immunosuppressive toxins and eminently compromise human immune systems exposing them to opportunistic bacterial or mycotic infections (Enyiukwu et al., 2017). Due to the extreme degree of toxicity of trichothecenes they have been used as biological weapons. In mice, it was noted that the most acutely toxic trichothecene is verrucarin $\mathrm{J}(0.5$ $\mathrm{mg} / \mathrm{kg}$ ), followed by T-2 and nivanenol which are nearly equitoxic (Coulunba, 1993). This group of fungi-derived toxins exerts multi-organ effects on biological systems resulting in some forms of emesis, diarrhoea, cardiovascular alterations, bone marrow damage, and decreased reproduction. Neurological disorders such as cognitive disturbances, delirium, and dementia as well as balance dysfunction have also ensued from exposure to trichothecenes. In Poland, about 13 children exposed to trichothecenes in indoor air of water damaged buildings experienced cognitive disturbances (Hope, 2013). Ingestion of significant amounts of fumonisin toxins have been associated with alimentary toxic aleukia (ATA) a disease which resembles severe radiation injury. It is characterized by a burning sensation in the mouth, tongue, throat, gut, and stomach and other symptoms such as nausea, vomiting, diarrhoea, leukopinea, haemorrhaging, skin inflammation, vertigo, asphyxiation and death (Table 2). In sub-lethal doses the toxins could trigger tremogenic effects or cause irritable bowel or colitis (Zain, 2017; Anon., 2017). Association of kwashiorkor a disease whose symptoms include fatigue, edema of the stomach, feet and ankles, weight loss, diarrhoea, loss of muscle mass and irritability with aflatoxin $B_{1}$ has been numerously reported (Eaton and Gallagher, 1994). According to Zain (2011) aflatoxin $B_{1}$ was also implicated in Reye's syndrome -- a debilitating disease which presents encephalopathy, visceral alteration and liver damage.

Contamination of food with fungal toxins is considered a plausible aetiological factor in Nodding Syndrome, a form of epilepsy affecting thousands of children in East Africa. The disease is said to be prevalent during periods of community displacement when food sources were unreliable and food quality was grossly compromised. Children that are affected with the disease developed eating- and cold-induced atonic seizures (with head nodding) and generalized seizures. According to Duringer et al. (2013) the mycotoxin beavericin associated with contaminating sorghum (a common East African staple) is regarded as the aetiological agent behind the disease. All 400 fungiderived toxins are toxic affecting human health in one way or the other. Recently a large number of medical practitioners have admitted that mould-caused human illness is a pandemic, and that exposure to toxic moulds is responsible for 500,000 deaths per year in the US alone (Chronicals, 2014). Some human diseases in which analytic and/or epidemiological data suggest or implicate mycotoxin involvement from exposure to, contact with, and inhalation of spores of fungal pathogens or ingestion of substrates contaminated by them are presented in Table 2. 
Table 2: Diseases caused by fungi-derived toxins in livestock and humans

\begin{tabular}{|c|c|c|c|}
\hline Disease & Species Affected & Substrate & Aetiological agent \\
\hline Akakabio-byo & Human & Wheat, barley, oats, rice & Fusarium spp. \\
\hline ATA or septic angina & Human & Cereal grains (toxic bread) & Fusarium spp., \\
\hline Balkan nephropathy & Human & Cereal grains & $\begin{array}{l}\text { Aspergillus spp. Penicillium } \\
\text { spp. }\end{array}$ \\
\hline Cardiac beriberi & Human & Rice & $\begin{array}{l}\text { Penicillium spp. Aspergillus } \\
\text { spp }\end{array}$ \\
\hline Celery harvester's disease & Human & Celery (pink rot) & Sclerotinia spp. \\
\hline Dendrodochiotoxicosis & Human, horse & Fodder, fodder dust & $\begin{array}{l}\text { Dendrodochium } \\
\text { toxicum }\end{array}$ \\
\hline Ergotism & Human & Rye, cereal grains & Claviceps purpurea \\
\hline Oesophageal tumours & Human & Corn & Fusarium verticillioides \\
\hline Hepatocellular carcinoma & Human & Cereal grains, peanuts & A. flavus, A. parasiticus, \\
\hline Kashin Beck disease, & Human & Cereal grains & $\begin{array}{l}\text { Fusarium spp. } \\
\text { Aspergillus }\end{array}$ \\
\hline Kwashiorkor & Human & Cereal grains & A. parasiticus \\
\hline Onyalai & Human & Millet & Phoma sorghina \\
\hline Reye's syndrome & Human & Cereal grains & Aspergillus spp. \\
\hline Sick building syndrome & Livestock, human & Hay, cereal grains, & Stachybotrys chartarum \\
\hline
\end{tabular}

Structures of some of the mycotoxins implicated in human mycoses are shown in Figs. 3-5. However, besides knowledge of the biology of the aetiological agents and chemistry of their toxins that bring about the mycotoxicoses in livestock and humans, appropriate understanding of the mode/mechanism of the damage of the toxins in biological and human systems could contribute immensely towards tailoring effective control strategies and management of the affected individuals (Enyiukwu et al., 2014).

\section{Modes of action (MOA) of mycotoxins on biological and human systems}

The mechanisms underpinning mycotoxin induced illnesses are suggested to involve oxidative stress, allergic responses, irritant effects, inflammation and some forms of toxicity and infection (Hope, 2013). Gliotoxins are immunosuppressive toxins and the virulence factors which play roles in human tissue colonization during infective mycoses; being selectively antagonistic to macrophages and lymphocytes and causing apoptotic and necrotic cell death. Chemically, they contain disulphide bridge which imparts their toxicity by inactivating host proteins and macrophages through reaction with thiol groups and generation of reactive oxygen species following redox cycling (Bernette and Klich, 2003; Gardiner et al., 2005; Enyiukwu et al., 2017).

Fumonisins are neurrotoxic, nephrotoxic and hepatotoxic compounds whose toxicity is thought to result from oxidative stress, apoptosis, cytotoxicity and 
alteration in cytokine expression of cells (StockmannJuvana and Savolaimen, 2008). Fumonisins are similar in structure to sphingolipids and in living cells and tissues their toxicity stems from binding to sphingolipid receptors and inhibiting the enzyme ceramid synthase leading to displacement and accumulation of sphingolipids in the systems. In nerve cells Zain (2011) noted also that they play roles in the inhibition of the uptake of folic acids via the folate receptors leading to neural tube defects.

Chemically aflatoxins (AFs) are a class of difuran-coumorins. They are of the naturally occurring potent carcinogenic fungal toxins which in mammals are reputed for being immunotoxic, genotoxic, hepatotoxic, mutagenic and to strongly damage kidney and liver tissues (Eaton and Gallanger, 1994; Hope, 2013). Besides $A$. parasiticus, $A$ nominus and related flora, species of Rhizopus, Penicillium and Mucor have been reported to produce AFs. Aflatoxin's toxicity is reasoned to stem from interference with the utilization of dietary protein by inhibiting synthesis of RNA, DNA and proteins. They are reported further to bind and destroy proteins of cell membranes, gap junctions and the intercellular matrix, disturbing cell to cell communication and thus causing tumorigenesis (Anon, 2017). The modes or mechanisms of action (MOA) of some mycotoxins in biological or human systems are summarized in Table 3.

In mammalian and eukaryotic cells, trichothecenes and other 12, 13-epoxytrichotecenes (sesquitriterpenoids) toxins inhibit protein and DNA synthesis. T-2 is an amphipathic trichothecene molecule.
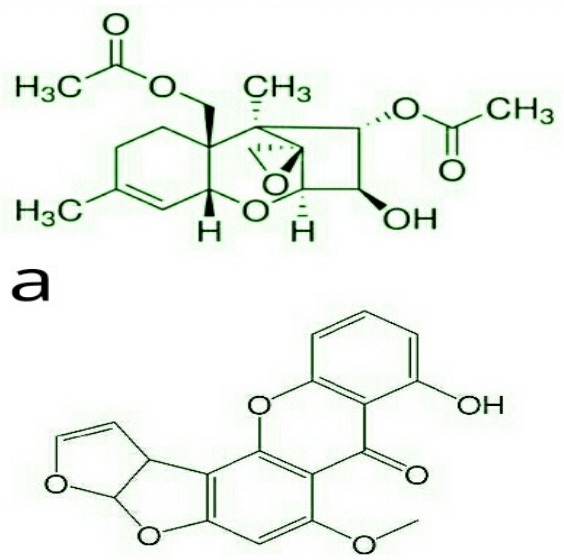

C

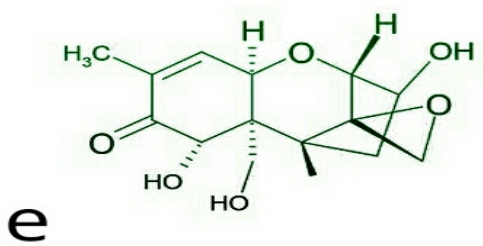

It is reported to interfere with membrane function by binding to lipid or protein moities of cell plasma membranes. In a study with mammalian tissues, 10 minutes after exposure to T-2 toxin, it was found to reduce the uptake of calcium, glucose, leucine and tyrosine (Coulumba, 1993). Others such as nivanelol, T2 toxins and verrucarin $A$ also, caused rapid breakdown of polyribosomes in $\mathrm{H}$-Hella cells and potently retarded polypeptide chain initiation in mammalian tissues. Similarly, inhibition of polypeptide chain elongation or termination is reported as the mode of injury of trichodermin (Cundliffe et al., 1974).

Fumonisins are dangerous mycotoxins. Coulumba (1993) noted that a link exists probably between short term dietary intake of fumonisin $B_{1}$ and hepatocellular carcinomas (HCC). Their mechanism of injury in several biological systems is thought to involve inhibition of protein synthesis and inactivation of critical enzymes (Table 3). Scabby grain disease, a disease affecting populations in Australia, China, Japan and USA symptomized by nausea, vomiting and diarrhea has been ascribed to the fusaria-derived toxins deoxynivalenol (DON) and Zearalenone (ZEN) (Zain, 2011). ZEN is an estrogen agonist. In biological systems zearalenone has been known to increase certain yeast and fungal infections and therefore could predispose or exacerbate certain opportunistic mycotic infections especially in people living with some forms of immunosuppressive diseases including cancers, HIV or undergoing chemotherapy such as prolonged prednisolone or dialysis therapy (Anon., 2017; Enyiukwu et al., 2017).
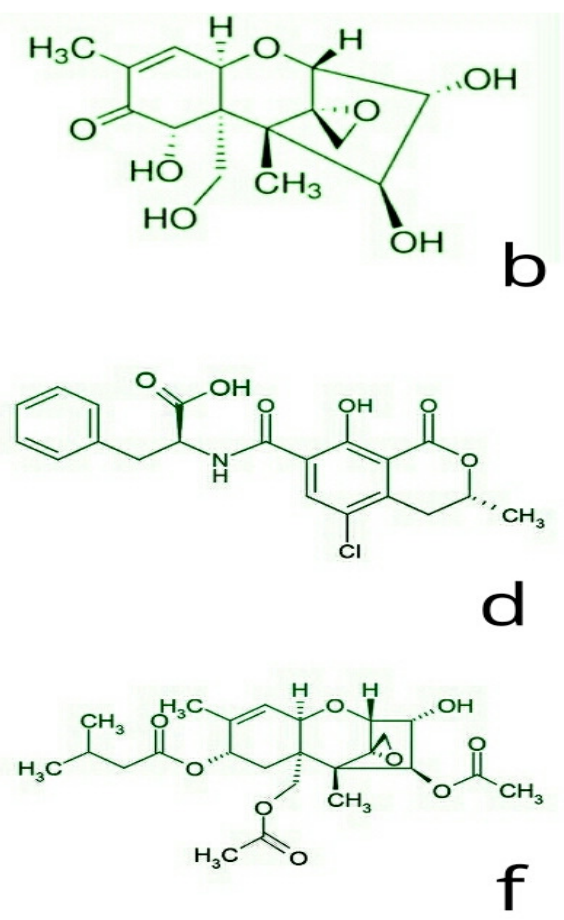

Figure 3: Structures of some common mycotoxins contaminating agro-products and causing indoor air pollution Key: $\mathbf{a}=$ Diacetylscripenol (DAS), $\mathbf{b}=$ nivanenol, $\mathbf{c}=$ Sterigmatocystin, $\mathbf{d}=$ Ochratoxin $\mathrm{A}, \mathbf{e}=$ Deoxynivanenol, $\mathbf{f}=\mathrm{T}-2$ toxin 
<smiles></smiles>

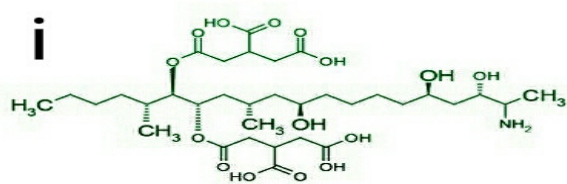<smiles>O=C1C=C2C(=CCOC2O)O1</smiles>

$\mathrm{k}$<smiles>C[C@H]1CCCC(=O)CCC/C=C/c2cc(O)cc(O)c2C1=O</smiles><smiles>CCCCCCCC</smiles>

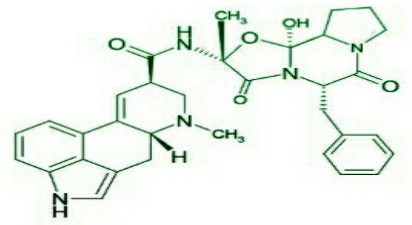

Figure 4: Structures of some common mycotoxins contaminating agro-products and causing indoor air pollution Key: $\mathbf{g}=$ Cyclopiazonic acid (CPA), $\mathbf{h}=$ zearalenone $(Z E R), \mathbf{i}=$ Fumonisin, $\mathbf{j}=$ Citrinin, $\mathbf{k}=$ Palutin, $\mathbf{I}=$ Ergot alkaloid

Sources: Mycotoxin Info; PubChem; ChemSpider.com; en.wikipedia.org

m<smiles>COc1cc2c(c3oc(=O)c4c(c13)CCC4=O)[C@H]1C=CO[C@@H]1O2</smiles><smiles>C=C(C)C(=O)/C(=C/C(=O)O)OC</smiles>

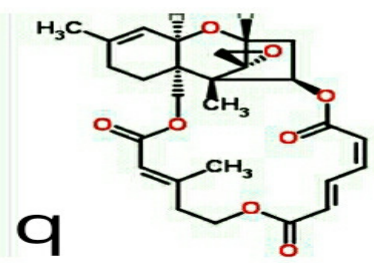<smiles>COc1cc2c(c3c1Oc1c(O)ccc(OC)c(c1=O)O3)[C@H]1C=CO[C@H](O2)O1</smiles>

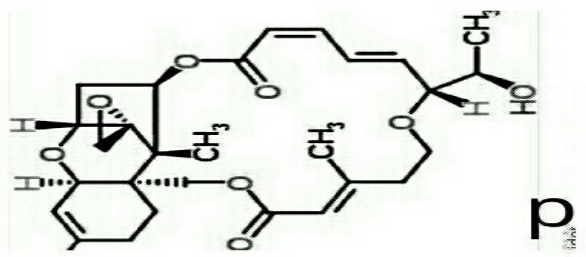

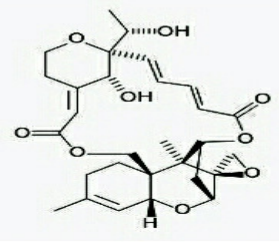

$r$

Figure 5: Structures of some common mycotoxins contaminating agro-products and causing indoor air pollution Key: $\mathbf{m}=$ Aflatoxin B1, $\mathbf{n}=5$-methyl Sterigmatocystin, $\mathbf{0}=$ Penicillic acid, $\mathbf{p}=$ Roridin, $\mathbf{q}=$ verrrucarin $\mathrm{J}, \mathbf{r}=\mathbf{s a t r a t o x i n} \mathrm{H}$

Sources: Mycotoxin Info; PubChem; ChemSpider.com; en.wikipedia.org

Zearalenone is thought to increase permeability of molecules across cell membranes and to promote synthesis of RNA, DNA and protein in the uterus (Anon., 2017). 
According to Mycotoxin Info (2016) T-2 toxin has a broad array of toxic effects on animals. The mechanism of its toxicity is common to other trichothecenes involving inhibition of protein synthesis followed by disruption of the synthesis of DNA and RNA which ultimately interferes with the metabolism of membrane phospholipids. This condition specifically affects rapidly dividing cells such as the ones of the intestinal mucosa, skin and lymph nodes, bone marrow, spleen, and thymus cells. Common symptoms in animals include feed refusal, weight loss, vomiting and inhibition of immunity. Other symptoms are diarrhea, gastritis, and emaciation, necrosis of cartilaginous tissues, apoptosis and death. Furthermore, alteration of hematic values like reduction of serum proteins and cholesteol levels has also been observed. Poultry is particularly sensitive to type A trichothecenes compared to other species and exhibit peculiar symptoms like mouth and tongue lesions (Cardwel, 2000; Mycotoxin Info, 2016).

The Ochratoxins (A, B, C) are usually chlorinated (unchlorinated) dihydro-isocoumarin derivatives bonded to phenylalamine through an amide. They affect several organs in the body including the liver, kidney, brain, heart, testicles, spleen and urinary bladder, immune system, and genes. Ochratoxin A (OTA) for instance have been implicated in Balkan endemic nephropathy and focal segmental glumerulosclerosis. Species of Penicillium, Petromyces, Neopetromyces, $A$. niger and $A$. ochraceous significantly produce these toxins (Hope, 2013). The toxicity of ochratoxins is pivoted on oxidative stress due partly to infringement of the activities of antioxidant enzymes such as catalases, superoxide dismuthase, gluthathione peroxide, gluthathione reductase, phenylalamine tRNA complex on the one hand, and inhibition of mitochondrial ATP (energy) production and increased lipid peroxidation in the kidney, liver and serum on the other hand (Anon., 2017).

Tenuazonic acid is a potent fungal toxin which has been linked to eosophagal cancer and onyalay (a haematological disorder) in some populations. Studies showed that birds and other test animals exposed to tenuazonic acid developed gizzard lesions, precancerous lesions and haemorrhaging. The mechanism of action of this toxin is thought to involve inhibition of synthesis of proteins by suppressing the release of newly formed proteins from ribosomes into the cell cytoplasm. (Blackmold, 2017).

Penitrem $A$ is a powerful neurotoxin, and tremogenic GABA agonist produced by $P$. crustosum. The toxin is capable of crossing the blood-brain barrier causing neurological diseases characterized by sustained limb weakness, ataxia, and convulsion which in most cases are under-diagnosed due partly to similarity of its symptoms to other such diseases. In the brain it attaches to GABA receptors disrupting electrical coordination which presents as cramp-like induction and oxidative stress (Moldes-Anaya, 2015). Exposure of persons to fungi in buildings that have microbial growth could result to several nervous system effects, rheumatoid diseases, loss of appetite, in addition to haemorrhaging of the mucous membrane of the intestinal and respiratory tracts. $S$. chartarum was suspected to be connected with pulmonary haemorrhaging in human infants in Cleveland, Ohio, USA. This organism secretes an enzyme stachyase which in concert with other toxins is thought to aid the pathogen to extract iron from susceptible host cells (NCBI, 2004).

Cyclopiazonic acid (CPA) exerts its toxic effects by impairment of the calcium metabolism that usually leads to damages to smooth muscles and the neural system (Suzuki et al., 1992; Mycotoxin.Info, 2016). Animal studies with rats revealed that CPA has an inhibitory effect on the endoplasmatic and sarcoplasmatic reticulum $\mathrm{Ca}^{2+}$-dependent ATPase which mediates the cellular $\mathrm{Ca}^{2+}$ pools (Suzuki et al., 1992; Uyamah et al., 1993). This effect is thought by Uyamah et al. (1993) to be consistent with the hypothesis that CPA induced decrease in stored $\mathrm{Ca}$ due to Ca-pump inhibition, reduced the $\mathrm{Ca}^{2+}$-dependent $\mathrm{K}^{+}$current and indirectly enhances $\mathrm{Ca}^{2+}$-influx through membrane activity resulting from the increased excitability in smooth muscles. In addition to neurotoxic effects, this metabolic disruption leads to immunomodulatory and immunosuppressive effects (Mycotoxin.Info, 2016). Furthermore this source reported that necrosis of liver, gastrointestinal tissue, kidneys and skeletal muscles have also been reported. CPA has implications in the promotion of carcinogenic effects in birds, specifically pathological changes in spleen and bursa fabricii.

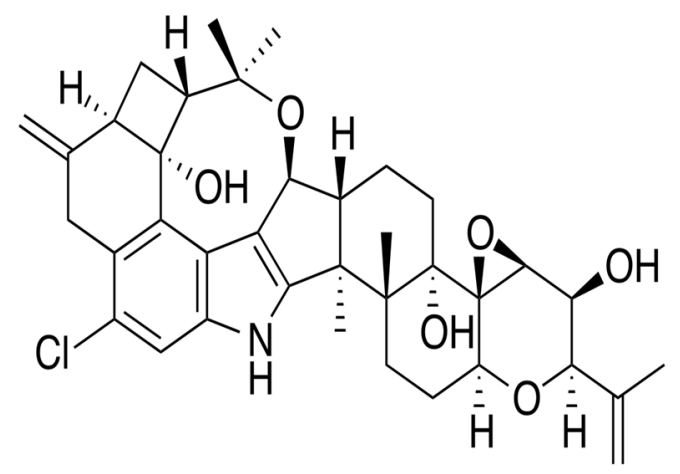

Penitrem A (Source: en.wikipedia.org)

Citrinin is nephrotoxic (Boudless, 2016), while citreoviridin, verrucosidin caused progressive paralysis of the limbs by impairing interneurons, and motor neurons of spinal cord and brain medulla. These toxins have been linked to CNS depression as well as respiratory and cardiovascular failures (Nishie et al., 1988; Viera et al., 1996). Some mechanisms of injury of mycotoxins on human and biological systems are summarized in Table 3 Palutin and its closely relative penicillic acid exert nephrotoxic (kidney) and immunotoxic effects. Patulin produces gastrointestinal symptoms like gastric ulcers, intestinal hemorrhages, 
lesions in the duodenum and alteration of intestinal barrier function (Mycooxin Info, 2016).

Human health effects of inhaling mycotoxins are grossly poorly documented despite presence of their large amounts in aerosols. According to Jean-Mark et al. (2010) amongst airborne mycotoxins sterigmatocystin is prevalent. Sterigmatocystin is a xanthone produced by strains of Aspergillus, Bipolaris and Emericella which occur in cereals, cheese, nuts coffee, bread cerealbased products. It is a genotoxic teratogen, mutagen, hepatogen and a possible human carcinogen. Animal studies using cattle suggested that symptoms of exposure to the toxin include loss of milk production, diarrhoea, renal lesions, hepatomas, and pulmonary tumours (Pubmed, 2017a; Blackmould, 2017b). Like aflatoxins and sterigmatocystin, their close derivative 5methoxysterigmatocystin a genotoxic carcinogen also contains furo-furan ring which is thought responsible for their biological activity (Jaksic et al., 2012). The mechanism of action (MOA) of sterigmatocystin is reported to be by binding to DNA, and uncoupling oxidative phosphorylation without causing swelling of the mitochondria. It inhibits acylCoAcholesterol acyltransferase (ACAT) with selectivity for ACAT-2 isoenzyme (www.toku-e.com).

Strains of the fungal saprophyte Trichoderma spp. (especially $T$. viride and $T$. hazianum) produce a class of antibiotic and toxic secondary metabolites generally called peptaibiols. Alamethicin is member of this class of membrane acting toxins others are emodin, suzukacillin, and trichodermin. They are suspected to play roles in sick building syndromes which accompany water damage buildings (Table 1.). Alamethicins impair voltage-gated ion channels in the lipid bilayers of cells (www.caymanchem.com/alamethicin/cas27061-7B-5). Fringeli et al. (1979) suggested that its injury on affected tissues is as a result of binding and incorporating itself into cell membranes and creating pores in the matrix; which could lead to loss of radicals (Nasery et al., 1979).

Penicillic acid is another important airborne mycotoxin produced by $A$. flavus and $P$. roqueforti through acid degradation of penicillins in water damaged environments. It is also known to contaminate corn and cereal grains. Penicillic acid exhibits a broadspectrum of activity including cytotoxic, mutagenic, genotoxic and tumorigenic carcinogenic activities. Its heart attacking activity has also been reported (Blackmould, 2017c). According to Kang and kim (2004) penicillic acid is strongly fungitoxic; it induced abnormal hyphal branching and apical swelling in Phytophtora spp. The mechanism of its injury on susceptible organisms is reported to involve inducing single stranded DNA breaks, inhibiting DNA synthesis in Chinese hamster ovary $(\mathrm{CHO})$ cells, irreversibly inactivating GDP-mannose dehydrogenase and interrupting algnate biosynthesis (PubChem, 2017: www.scbt.com/penicillic-acid/AKR1A1...).

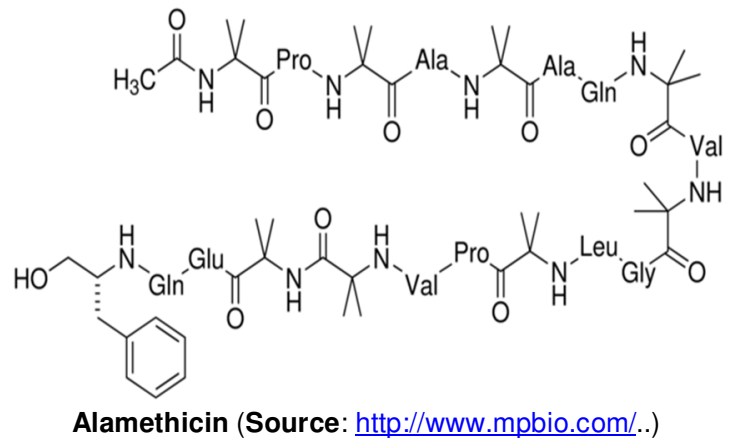

Nephrotoxic glycopeptides are another class of fungi-derived toxins. Some such as vancomycin has found medical importance as broad-spectrum antibiotic (https://pubchem.ncbi.nlm.nih.gov/compound/vancomyci n\#section). This class of substances however, could cause nephrotoxicity which usually results in increased serum creatinine levels. They are produced by Penicillium aurantiogriseum and have been implicated as one of the mycotoxins responsible for sick building syndrome (Table 1). Affected individuals may present headache, dizziness and taste disturbances (www.medweb.tulane.edu>doku.php>glycopeptides).

Nephrotoxic glycopeptides are large molecules and are noted to have very complex structures. In Yugoslavian $P$. aurantiogriseum isolates from a village in which the idiopathic human Balkan nephropathy disease is hyperendemic, showed a similar nephropathology in mice and were acutely cytotoxic, hence reinforcing a need to regarding this novel Penicillium nephrotoxin as a potential factor in human nephropathy (Yeullet et al., 1988). Tests with bacteria showed that nephrotoxic glycopeptides inhibit the synthesis of cell walls and peptidoglycan synthesis by infringing the addition of new amino acid units to it. The mechanism of this action is reported to involve binding to acyl-D-alanyl-D-alanine terminals of growing peptide chain, inactivating the enzyme transpeptidase and thus prevents further elongation and cross linking of peptiglycan matrix in bacteria (www.medweb.tulane.edu>doku.php>glycopeptides) ${ }^{*}$

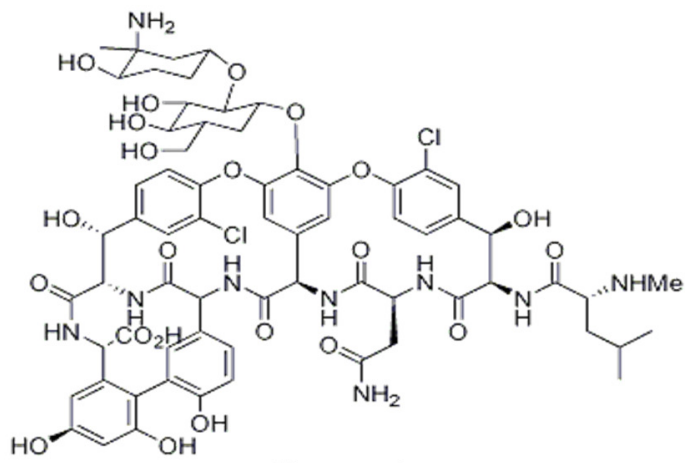

Vancomycin (A nephrotoxic Antibiotic) (Source:chem257.pbworks.com) 
Beavericin (BEA) is a lipophillic hexadepsipeptide mycotoxin. It is produced by the entomophagous fungi Beauvaria basiana, F. semitectum, F. sabtlutirans and Fusarium spp. Also, strains of Polyporus spp., Plaeceliomyces spp. and Isaria spp. are known to produce the toxin alongside other toxins such as dextuxins, bassianolide, efrapeptins, tenellin and oosporecin. Beauvericin is associated with the contamination of sorghum, corn, corn products and cereals. It has good insecticidal and herbicidal properties. It also exhibited antimicrobial, cytotoxic, and potent anticancer activities; and induced apoptosis in mammalian cancer lines due to inhibition of calcium ion $\left(\mathrm{Ca}^{2+}\right)$ flux in cells (Logrieco et al., 1998; Sood et al., 2017). Beavericin closely resembles the eniatin antibiotics, however, they seem to differ in target (Wang and $\mathrm{Xu}, 2012)$. Unlike penicillins and nephrotoxic glycopeptides (eniatin antibiotics) which are cell membrane or cell wall inhibitors, beauvericin targets cell organelles, nucleus and enzymes (Sood et al., 2017). This compound is a specific cholesterol acyltransferase inhibitor. It has been reported to be toxic to several human cell lines and to induce programmed cell death through cytolysis followed by internucleosomal DNA fragmentation (Logrieco et al., 1998). Furthermore, Duringer et al. (2013) was of the opinion that BEA formed ionophores in membranes, disturbed intracellular calcium ion homeostasis, disrupts cellular metabolism and induces apoptosis Besides toxicity to mammalian cells, beavericin due to its antimicrobial, insecticidal and herbicidal properties is considered a potential and novel agent for pesticides and medicines and hence requires further scientific studies (Wang and Xu, 2012).

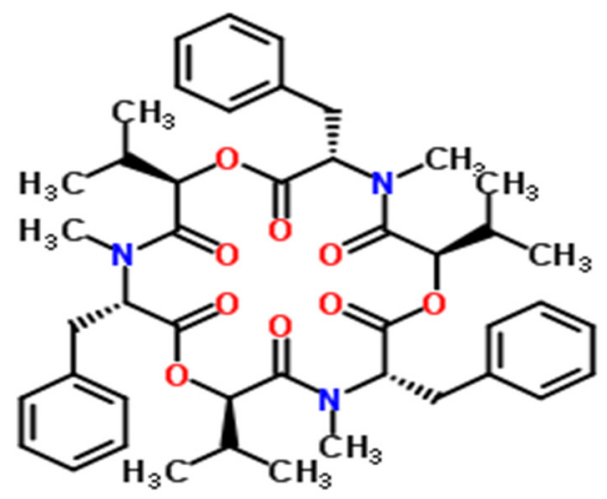

Beauvericin (Source: www.chemSpider.com)

\section{Management of mycotoxicosis in humans}

Though contamination of agricultural products with fungiderived toxic metabolites is not entirely avoidable, good agronomic and farm practices are surely the starting point of their control (Coulombe, 1993). Surveys suggest lower incidence of mycotoxin contamination of agroproducts and mycotoxicoses occurred in developed economies of the world than the developing nations
(Shephard, 2008; Darwish et al., 2010). According to Shephard (2008) good agronomic, manufacturing and marketing practices as well as strict legislative controls in Europe and America are seen as the reasons behind this development.

Management of mycotoxins and mycotoxicosis especially in the African context however, will require holistic approach, beginning from the farm through the value chain lines and many of the control approaches may be used in integrated systems (Enyiukwu et al., 2014). Management methods involving field and store hygiene, good value chain protocols and use of plantderived extracts for the reduction of mycotoxin contamination on agro-products and their attendant health burden of consumers have been reviewed by Enyiukwu et al. (2014). Early identification and segregation of contaminated kernels of corn, peanuts and other grains is a welcome strategy. This for example could be done by use of electronic equipment (eequipment) that identify and reject grains that exhibit fluorescence due to aflatoxins (Coulunba, 1993). In feed processing factories, ammoniation of cotton seed and cotton; as well as addition of binders such as sodium calcium aluminosilicate (anticaking agent) has been found to significantly reduce the bioavailability of $\mathrm{AF}_{1}$ (Coulumba, 1993; Enyiukwu et al., 2014). Such measures could contribute to reducing to a large extent biological magnification of these noxious toxins in the food chain (Enyiukwu, 2002).

In endemic areas proper physical exercising (or exposure to 'sauna') is imperative for offsetting the adverse effects of some mycotoxins in the body. It is reported that activities involving sweat induction reduces the burden of nephrotoxic carcinogenic OTA since it is excreted from sweat. And therefore may prove valuable in the management of chronic intermittent exposures. Also, nutritional fortification, amendment and improvement of cereals and tubers and commonly consumed tropical staples during processing along value-chain lines with vitamins $A, C, D$ and $E$ and whey proteins are reported to significantly reduce the effects of mycotoxins on consumers by providing co-enzymes, reducing lipid peroxidation and acting as oxidative stress breakers. Korean ginseng, curcumin, chlorophyll, extracts of Glyrrhizia glabia and Liqourice plant have also been shown to protect vulnerable body organs or to reasonably reverse and eliminate the biochemical changes that took place in mycotoxin-affected organs or tissues possibly by antioxidant activity, or strengthening some enzymatic pathways. Breeding for mycotoxins resistant cultivars and/or biotechnologically modifying commonly consumed staples such as orange flesh sweet potato, tubers and cereals with ability to produce significant amounts of vitamins $A, C, D$ and $E$ and certain flavonoids which will not be lost during processing will undoubtedly contribute to ameliorating mycotoxicosis in livestock and humans.

Other interventions involve chemotherapy using melatonin, gluthathione and related antioxidants. In acute attacks, sequestering agents such as charcoal 
Table 3: Modes of action (MOA) of some mycotoxins in biological and humans systems

\begin{tabular}{|c|c|c|c|c|}
\hline Mycobiota & Mycotoxin Produced & Disease(s) caused & Symptoms & MOA \\
\hline Fusarium spp. & Fumonisins & Akakabio-byo & & $\begin{array}{l}\text { Inhibits ceramide synthase } \\
\text { and disrupts sphingolipid } \\
\text { metabolism }\end{array}$ \\
\hline $\begin{array}{l}\text { F. sporotrichioides, } \\
\text { F. Poae }\end{array}$ & $\begin{array}{l}\text { Trichothecenes } \\
\text { Diacetoxyscirpenol) }\end{array}$ & $\begin{array}{l}\text { Alimentary } \\
\text { aleukia (ATA) }\end{array}$ & $\begin{array}{l}\text { Oesophal } \\
\text { gastroenteritis, vains, } \\
\text { laryngitis, mucus membrigo, } \\
\text { hyperaemia, leukopenia, } \\
\text { skin inflammation and death }\end{array}$ & $\begin{array}{l}\text { Bind to ribosomes and } \\
\text { mitochondria, inhibits } \\
\text { peptidyl transferase activity; } \\
\text { protein and DNA synthesis. } \\
\text { Immunosuppressive agents, } \\
\text { decreasing immunoglobins } \\
\text { and the formation of } \\
\text { coagulation factors and } \\
\text { hence opens up the host to } \\
\text { opportunistic infections. }\end{array}$ \\
\hline Penicillium spp. & Ochratoxin A & Balkan nephropathy & $\begin{array}{l}\text { Tubule interstitial nephritis; } \\
\text { kidney, pelvis, ureter, and } \\
\text { urinary bladder tumors }\end{array}$ & $\begin{array}{l}\text { Genotoxic interfering with } \\
\text { gene transcription due to } \\
\text { activation via co-oxidation } \\
\text { through the prostaglandin } \\
\text { synthase (P-H) route. } \\
\text { Stimulates lipid } \\
\text { peroxidation, inhibits } \\
\text { enzymes involved in } \\
\text { synthesis of phenylalamine } \\
\text { tRNA complex, and } \\
\text { mitochondrial } \\
\text { production). Toxicity is } \\
\text { thought to result from } \\
\text { oxidative stress }\end{array}$ \\
\hline
\end{tabular}

Aspergillus spp., Citreoviridin
Penicillium spp. $\begin{array}{ll}\text { Cardiac beriberi } & \text { Causes CNS depression, } \\ \text { (Yellow rice disease) } & \text { respiratory and }\end{array}$

\section{Sources}

Voss et al. (2007)

Zain (2011);

Enyiukwu et al. et al.

(2014); Anon (2017)

$\begin{array}{ll}\text { laryngitis, mucus membrane peptidyl transferase activity; } & \\ \text { hyperaemia leukopenia, protein and DNA synthesis. }\end{array}$

hyperaemia, leukopenia, protein and DNA synthesis.

decreasing immunoglobins

and the formation of

agulation factors and

opportunistic infections.

cardiovascular failure,

shortness of breath, and leg

swelling, numbness of the

hands and feet, confusion,

trouble moving the legs, and

In affected individuals, it

Inhibits protein synthesis

Nishie et al (1988);

Vieta et al. (1996);

Voss et al. (2007)

Ency. of Food Mycotoxins 2017 yiukwu et al. (2014)

Anon. (2017); Surai et al. (2010)

pain, loss of appetite

and constipation , dyspnea,

gaspin, coma and death 


\begin{tabular}{lll}
\hline $\begin{array}{l}\text { Sclerontinia } \\
\text { sclerotiorum }\end{array}$ & $\begin{array}{l}\text { Psoralens (Xanthotoxin, } \\
\text { begapten) }\end{array}$ & $\begin{array}{l}\text { Celery harvester's } \\
\text { disease }\end{array}$
\end{tabular}

sclerotiorum

begapten)

disease

Claviceps purpurea Ergot alkaloids

Ergotism

Aspergillus flavus, Aflatoxin $\mathrm{B}_{1}$ A. Parasiticus

Hepatocarcinoma (HCC) ((Fig. 6))
Photodermatitis, vesicular and produced on human and animal

\section{Aspergillus flavus. Aflatoxin $\mathrm{B}_{1}$} A. Parasiticus

Fusarium

verticillioides,

Fumonisin $\mathrm{B}_{1}$

Proliferatum

yellow skin and eyes, dark bullous lesions on human skin irradiated by natural sunlight, erythematous, edematous, and pigmentary lesions can be skins

Necrotic or gangrenous symptoms - colds, prickling sensation in limbs, muscular pains, intense heat in limbs, loss of limbs, acute convulsion or drowsiness, death or mental impairment

Pain in the upper right part of the belly, a lump or feeling of heaviness or swelling in the

belly, loss of appetite and feelings of fullness, weight loss, weakness or

deep fatigue, nausea,

vomiting. urine and pale, chalky bowe movements, and fever

Kwashiorkor (Fig. 6)

Neural tube defects

(Fig. 6)
Severe protein-energy

malnutrition characterized

by edema, irritability,

ulcerating dermatoses, and an enlarged liver

Perturbs protein-calorie metabolism, promotes immune toxicity resulting from inhibition of T-cell and macrophages

Defects of the brain, spine, first month of pregnancy

Inhibits

cytokines

ceramide synthase sphingolipid-dependent or spinal cord. Usually in the cell surface membrane alterations, probably disrupts the phosphorylation epidermal growth factor (EGF) (transmembrane glycoprotein) with tyrosine kinase activity
Binds to $\alpha$-adrenoreceptors inhibits $\beta$-adrenoreceptors,

cause convultions, gangrenous and serotinine syndromes. Vasoconstriction, uterine constraction and inhibition of prolactin secretion.

Inhibits activity of $P_{53} \quad$ Kew et al. (2013) tumour suppressor gene at codon 299

www.webmd.com /cancer/hepa...
1989), Horsfall

(2012)

www.accessdata.fda.gov/ scripts plantox/detail.cfm

\section{Horsfall (2012), Anon}

and Missmer et al. (2006); functions
Enyiukwu et al. (2014)

en.wikipedia.org 


\begin{tabular}{|c|c|c|c|c|c|}
\hline $\begin{array}{l}\text { Fusarium } \\
\text { verticilloides, } \\
\text { Proliferatum }\end{array}$ & Fumonisin $\mathrm{B}_{1}$ & Oesophageal tumors & $\begin{array}{l}\text { Dysphagia, weight loss, } \\
\text { bleeding and vomiting of } \\
\text { blood, passing melana, Iw } \\
\text { blood count, abdominal or } \\
\text { chest pain, and hoarse } \\
\text { voice. }\end{array}$ & $\begin{array}{l}\text { Inhibits ability of cells to } \\
\text { proliferate (Pitt, 2000), } \\
\text { induces loss of electrolyte in } \\
\text { affected cells }\end{array}$ & $\begin{array}{l}\text { Enyiukwu et al. (2014). } \\
\text { www.medicinenet.com/ } \\
\text { esophageal_cancer/... }\end{array}$ \\
\hline $\begin{array}{l}\text { Phoma sorghina, } \\
\text { Alternaria spp. }\end{array}$ & $\begin{array}{l}\text { *Tenuazonic } \\
\text { moliniformin }\end{array}$ & $\begin{array}{l}\text { Onyalai, oesophageal } \\
\text { cancer (Fig. 6) }\end{array}$ & $\begin{array}{l}\text { Hemorrhagic lesions on oral, } \\
\text { nasal, and subconjunctival } \\
\text { mucous membranes, skin, } \\
\text { and soles of feet, hematuria, } \\
\text { melena and menorrhagi, } \\
\text { chronic thrombocytopenia. }\end{array}$ & $\begin{array}{l}\text { Inhibits fribroblasts, cell } \\
\text { proliferation and protein } \\
\text { synthsis }\end{array}$ & $\begin{array}{l}\text { Rabbie et al., (1975); } \\
\text { Zhou and Quang, 2008; } \\
\text { Blackmold, 2017) } \\
\text { en.wikipedia.org }\end{array}$ \\
\hline Aspergillus spp. & Aflatoxin $\mathrm{B}_{1}$ & Reye's syndrome & $\begin{array}{lr}\text { Encelopathy, } & \text { visceral } \\
\text { deterioration, } & \text { kidney/liver } \\
\text { enlargement } & \end{array}$ & of protein & $\begin{array}{l}\text { Ryan et al. (1979); Zain } \\
(2011) \text {; Sura et al. } \\
(2010) \text {. }\end{array}$ \\
\hline Stachybotrys atra & $\begin{array}{l}\text { Roridin E, Verrrucarin J, } \\
\text { satrotoxin H }\end{array}$ & Sick building syndrome & $\begin{array}{l}\text { Headache, eye, nose and } \\
\text { throat irritation, fatigue, } \\
\text { dizziness and nausea. }\end{array}$ & of protein & $\begin{array}{l}\text { Volk and Zitomer } \\
(2002)\end{array}$ \\
\hline $\begin{array}{l}\text { A fumigatus; } \\
\text { Albicans }\end{array}$ & Gliotoxins & $\begin{array}{lr}\text { Participates in host } \\
\text { tissue } & \text { marceration } \\
\text { during } & \text { invasive } \\
\text { mycoses } & \end{array}$ & NA & $\begin{array}{l}\text { Inhibits macrophages, } \mathrm{T} \text { - } \\
\text { cells activation and } \\
\text { proliferation }\end{array}$ & Voss et al. (2007) \\
\hline $\begin{array}{l}P . \quad \text {.palutin, } \\
\text { custosum, } \\
\text { Expansum }\end{array}$ & Palutin, & Kidney damage & $\begin{array}{l}\text { gastrointestinal symptoms } \\
\text { like gastric ulcers, intestinal } \\
\text { hemorrhages, lesions in the } \\
\text { duodenum and alteration of } \\
\text { intestinal barrier function }\end{array}$ & $\begin{array}{l}\text { Palutin binds to sulfhydryl } \\
\text { groups in proteins and } \\
\text { amino acids in the plasma } \\
\text { membrane }\end{array}$ & $\begin{array}{l}\text { Mycotoxin Info, 2017; } \\
\text { Surai et al. (2010) }\end{array}$ \\
\hline $\begin{array}{l}P . \quad \text { cyclopium, } A . \\
\text { tamari, } A \text {. flavus, } P \text {. } \\
\text { Viricatum }\end{array}$ & Cyclopiazonic acid (CPA) & $\begin{array}{l}\text { Liver necrosis; nerve } \\
\text { cells damage }\end{array}$ & 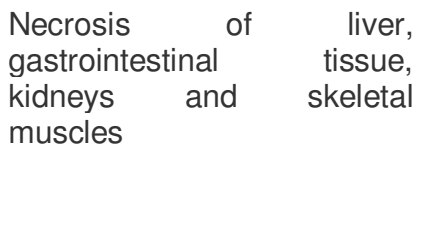 & $\begin{array}{l}\text { Impairs calcium metabolism, } \\
\text { damages to neural system, } \\
\text { inhibits cellular ATPase in } \\
\text { the endoplasmic reticulum } \\
\text { (ER), and impairs neural } \\
\text { systems. }\end{array}$ & Mycotoxin Info, 2017 \\
\hline
\end{tabular}




F. culmorum, F. $\quad$ Deoxynivanelol (DON) Mitochondrial
graminaerum

dysfunction
Estrogen agonists

gastroenteritis
impaired gut
integrity, diarrhea;
intestinal bleeding;
anorexia; increased
liver size, reduced
weight gain and
severe

severe

immunosuppression

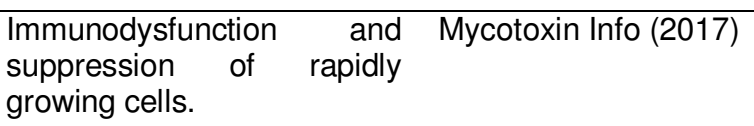

Early puberty in girls, sexual disorders, alteration in development apparatus

of sexual

Influences transcription in

culmorum

verticillioides

membrane permeability of

protein and promotes synthesis of proteins, RNA and DNA by the uterus

*Suspected mycotoxin. NA = Not available

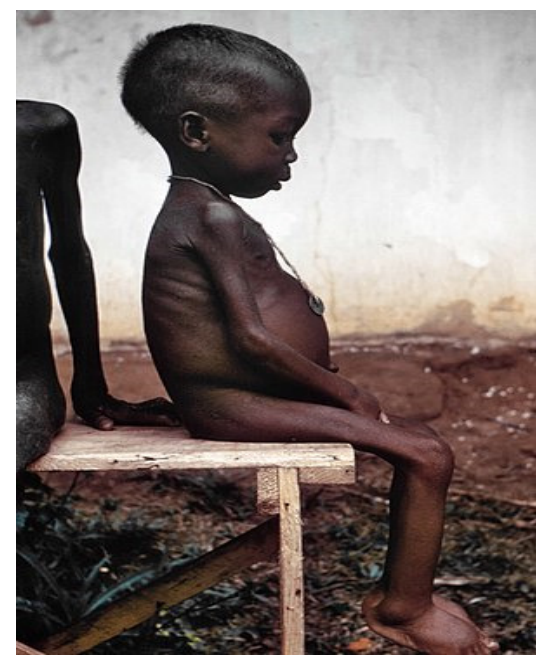

A (Kwashiokor)

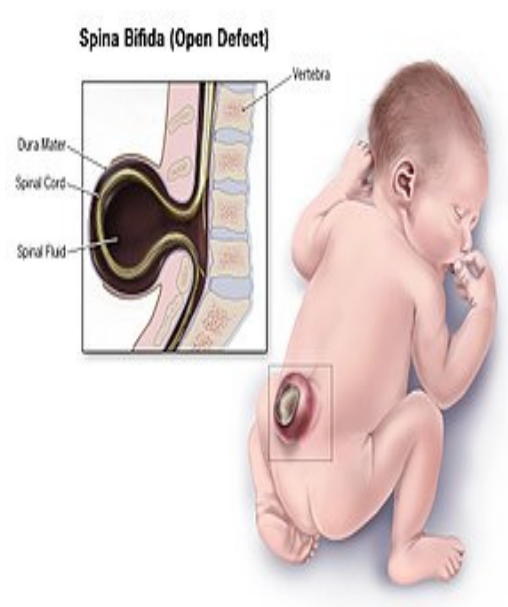

B (Neural Tube Defect)

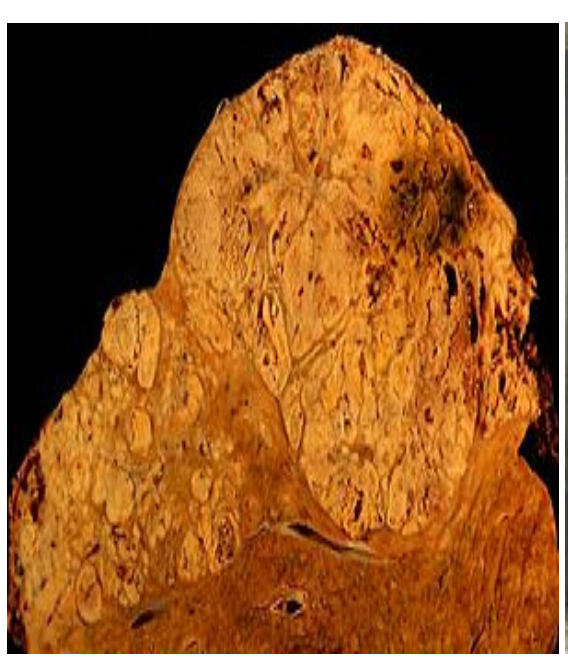

C (Liver with HCC)

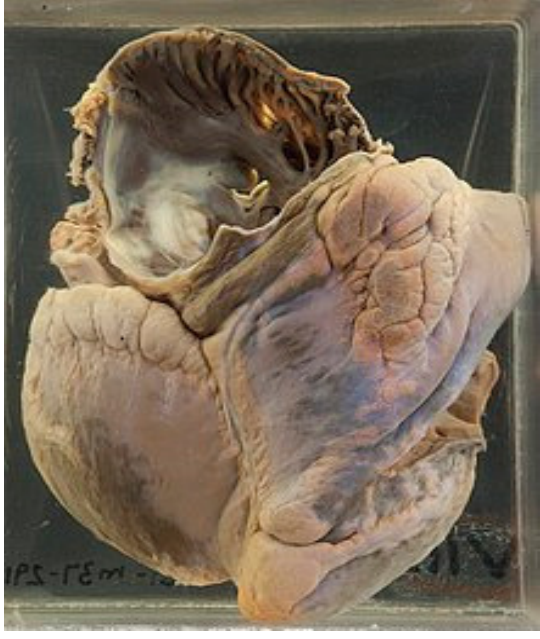

D (bleeding heart due to onyalai)

Figure 6: Some serious diseases in which mycotoxins have been implicated in humans around the world Source: en.wikipedia.org 
which bind, absorb or adsorb the fungi-derived toxins may be administered by health professionals in standard clinics and hospitals (Hope, 2013). So far however, there is no cure for mycotoxicosis. Antibiotics and drugs have little effects on the toxins. Blackmold (2017) holds the opinion that the best management approach is to avoid or stop the exposure to mycotoxins especially indoors through:

$>$ Proper home hygiene. Fix leaking roof as soon as possible to avoid saprophytes from colonizing your roof racks and ceiling. Ensure you also repaint kitchen and bathroom walls regularly to avoid build up of mycotoxigenic saprophytes on them. For this reason also wash bathtubs regularly with sodium hypochlorite (bleach).

$>$ Do not store agro-produce for too long before consuming them especially fruits, nuts such as peas and vegetables except where refrigerated.

$>$ If you perceive musty odours in your home or office quickly report this to appropriate environmental professional to screen your house.

$>$ If you feel uncomfortable after ingesting a particular agro-produce, consult a clinicians to examine you and possibly samples of the ingested food material for signs and symptoms of mycotoxins or toxic moulds.

$>$ Service your air conditioners regularly as these could be havens for Aspergillus spp. and other toxic moulds.

\section{ACKNOWLEDGEMENTS}

The authors sincerely thank Prof. Amaechi N. of the Department of Veterinary Microbiology College of Veterinary Medicine and Dr T. Ubani of the Department of Plant Health Management, College of Crop and Soil Sciences of the Michael Okpara University of Agriculture, Umudike for pre-publication review and criticism of this manuscript

\section{REFERENCES}

Adejumo, T. O. and Adejumo, D. O. (2014). Incidence of aflatoxins, fumonisms, trichotecenes and ochratoxins in Nigeriafoods and possible intervention strategies. Food science and Quality Management 31:126-147.

Amadi, J. E. and adeniyi, D. o. (2009). Mycotoxins production by fungi isolated from stored grains. African J. of Biotecnology 8(7): 1219-1221.

Anon. (2017). Fungal exposure: toxicity and immunology. $\quad$ www.nutrispec.net>articles>pdf>Fungal_Exposure...Accessed July 31, 2017.

Blackmold (2017). Tenuazonic acid. In: Toxic black mould information about mould and mould diseases. www.blackmould.me.uk Accessed July 20, 2017.
Bennette, J. W. and Klich, M. (2003). Mycotoxins. Clinical Microbiology Reviews 16: 497-516

Boundless (2016). Toxins. wwww.boundless.com/microbiology...toxins-8175780

Bryden, W. L. (2012). Food and feed, mycotoxins and the perpetual pentagram in a changing animal production environment. Animal production Science 528: 385-397.

Cardwell, K. E. (2000). Mycotoxin contamination of foods in Africa: Antinutritional factors. Food Nutrition Bulletin 60(4): 488-492.

Chronicles, S. (2014). Mycotoxicosis Information and Symptoms List https://spoonielife.wordpress.com/2014/06/16/moldillness-websites-information Accessed December 22, 2017.

Coulombe, R. A. Jr. (1993). Biological action of mycotoxins. Journal Diary Science 76: 880-891

Cundliffe, E., Cannon, M. and Davies, J. (1974). Mechanism of inhibition of eukaryotic protein synthesis by trichothecene fungal toxins. Proceedings Nat, Academy Sci. USA No 1 pp30-34.

Darwish, W. S., Ikenaka, Y., Nakayama, S. M., Ishizuka, M. (2014). An overview on mycotoxin contamination of foods in Africa.J. Vet Med. Sci. 76(6):789-97 [Epub]

Duringer, M., Morrie, C. A., Palmer, V. S. and Spencer, P. S. (2013). Beauvericin in Sorghum Proximate to Nodding Syndrome Jennifer. International Conference on Chemical, Agricultural and Medical Sciences (CAMS-2013) Dec. 29-30, 2013 Kuala Lumpur (Malaysia).

Eaton, D. L. and Gallangher, E. P. (1994). Mechanism of aflatoxin carcinogenisis. Annual Reviews Pharmacology Toxicology 34: 135-172.

Enyiukwu, D. N. Ononuju, C. C. and Maranzu, J. O. (2017). (Accepted) Plant pathogenic fungi - Novel agents of human diseases: Implications for public health. Greener Journal of Epidemiology and Public Health (Galley Proof).

Hope, J. (2013). A review of the mechanism of injury and treatment approaches for illness resulting from exposure to water damaged buildings, molds and mycotoxins. The Science World Journal 767462

Hosfall, J. G. and Cowlong, E. B. (2012) (Eds) Plant Disease an Advanced Treatise Vol. IV. How Pathogens Induce Disease. Academic Press NY.

Kew, M. C. (2013). Aflatoxins as cause of hepatocellular carcinoma.J. Gastrointestinal and Liver Diseases 22(3): 305-310.

Laskin, J. D. (1989). Mechanisms of psoralen action in the skin. International Journal Toxicology 8(5): 797800.

Logrieco, A., Moretti, A., Castella, G., Kostecki, M., Golinski, P., Ritieni, A. and Chelkonski, J. (1998). Beauvericin. Applied Enviromental microbiology 84(3): 3084-3088. 
Missmer, S. A., Suarez, L., Fekner, M., Wang, E., Merill, A. H. Jr., Rorhman, K. J. and Hendricks, K. A. (2006). Exposure to fuminosins and the occurrence of neural tube defects along the Texas-Mexico border. Environ. Health Prospects 14(2): 237-241.

Moldes-Anaya, A. (2015). Fungus-induced neurological diseases: an underestimated risk for animals and humans.

www.sciencedaily.com/releases/12/1112...htm

Mycotoxin Info (2016). Common mycotoxins.

http://www.mycotoxins.info/en/mycotoxins/commonmycotoxins/...Acessed October 2, 2016

Mycotoxin Info (2017). Common mycotoxins.

http://www.mycotoxins.info/en/mycotoxins/commonmycotoxins/...Accessd June 30, 2017

NCBI (National Center for Biotechnology Institute) (2004). Toxic effects of bacteria and fungi. www.ncbi.nim.nih.gov Accessed July 30, 2017..

Nishie, k., Cole, R. J. and Dorner, J. W. (1998).Toxicity of citreoviridin.Research Commun. Chem. Pathol. Pharmacol. 59(1): 3-52.

Oyeyipo, O. O., Iwunji, C. A. and Owhoeli, O. (2012). Public health implications of mycotoxin contaminated pawpaw (Carica papaya L.) on sale in Nigerian market . Int. Joural Health Research 5(1): 023-027.

Peraica, M., Radic, B., Lucic, A. and Palovic, M. (1999). Toxic effects of mycotoxins in humans. Bulletin of the WHO 77(9): 755-766.

Pitt, J. I. (2000). Toxigenic fungi and mycotoxins. British Medical Bulletin (BMB) 56(1): 184- 192.

Rabbie, C. J., van Rensburg, S. J., van der Wat, J. T. and Lubben, I. (1975). Onyalai - the possible involvement of a mycotoxin produced by Phoma sorghina in the aetiology. SA Medical Journal (Suppl. SA J. Nutri) 1647-16501: 57-60.

Riley, R. T., Kenneth, A. V., Speer, M., Stevens, V. L., van Waes J. W. (2006). Fumonisins inhibitor of ceramide synthase: A possible risk factor for neural tube defects. In: Yoshino, H., Yasuyiki, I., Merill Jr., A. H. (Eds.) Sphingolipid biology pp 345-361. link.springer.com/chapter/10.1007\%2F4...

Ryan, N. J., Hogan, G. R., Hayes, H. W., Unger, P. D. siral, M. Y. (1979). Aflatoxin B1 role in the aetiollogy of Reye' syndrome. Paediatrics 64(1): 71-75 [PubMed]

Shephard G. S. (2008). Impact of mycotoxins on human health in developing countries. Food Additives and Contaminants 25(2): 146-151.
Sood, S., Sandhu, S. S.. and Mukherjee, T. K. (2017). Pharmaceutical and Therapeutic potentials of beauvaricin: A short review. J. Proteomics and Bioinformations 10: 18-23.

Stockmann-Juavala, H. and Savoleiman, K. (2008). A review of the toxic effects of fumonisin B1. Human and Experimental Biology 27(11): 799-809.

Surai, P., Mezes, m., Fatima, T. I. and Denver, S. D. (2010). Mycotoxin in human diets: a hidden danger. www. feedfood.co.uk $>$ download $>$ mycotoxins.

Suzuki, M., Muraki, K., Imaizum,i Y. and Watanabe, M. (1992). Cyclopiazonic acid, an inhibitor of the sarcoplasmic reticulum $\mathrm{Ca}(2+)$-pump, reduces $\mathrm{Ca}(2+)$-dependent $\mathrm{K}+$ currents in guinea-pig smooth muscle cells. British J. Pharmacology 107(1):134-40.

Uyama, Y., Imaizumi, Y. and Watanabe, M. (1993). Cyclopiazonic acid, an inhibitor of $\mathrm{Ca}(2+)$-ATPase in sarcoplasmic reticulum, increases excitability in ileal smooth muscle. Br J Pharmacology 110(2):565-72.

Viera, I., Salvaino, A., Papa, G., Videtto, V., Cantamessa, C. and Pugliese, A. (1996). In vitro inhibitory activity of citreolinidin against HIV 1 and HIV 2 associated opportunistic Candida albicans. JournalChemotherapy Italy (PubMed).

Volks, T. and Zitomer, N. (2002). Stachybotrys chartarum: Tom Volks's fungus of the month November 2002. www.cdc.gov Accessed August 3, 2017.

Voss, K. A., G. W and Haschek, W. M. (2007). Fumonisins: toxicokinetics, mechanism of action and toxicity. Animal Feed and Technology 157(3): 299-325.

Wang, Q. and Xu, L. (2012). Beauvericin, a bioactive compound produced by fungi: A review. Molecules 17: 2367-2377.

Wild, C. P. and Gong, Y. Y. (2010). Mycotoxins and human disease: a largely ignored global health issue. $\quad$ Carcinogenesis 31(1): 71-82. doi: $10.1093 /$ carcin/bgp264.

Yeullet S. E., Mantle, P. G., Rudge, M. S., Greig, J. B. (1988). Nephrotoxicity of Penicillium aurantiogriseum, a possible factor in the aetiology of Balkan endemic nephropathy. Mycopathologia.102(1): 21-30.

Zain, M. E. (2011). Impacts of mycoxins on humans and animals. Journal of Saudi Chemical Society 15(2): 129-140. 